\title{
Addition of residues and reintroduction of microorganisms in Jatropha curcas cultivated in degraded soil
}

\author{
Adriana A. Santos ${ }^{1}$, José A. Agustini ${ }^{1}$ \& Katia L. Maltoni² \& Ana M. R. Cassiolato² \\ ${ }^{1}$ Universidade Estadual Paulista "Júlio de Mesquita Filho"/Faculdade de Engenharia. Ilha Solteira, SP. E-mail: adrianapsique@gmail.com; \\ agustini@bio.feis.unesp.br \\ ${ }^{2}$ Universidade Estadual Paulista "Júlio de Mesquita Filho". Ilha Solteira, SP. E-mail: maltoni@agr.feis.unesp.br; anamaria@bio.feis.unesp.br \\ (Corresponding author)
}

\author{
Key words: \\ Jatropha curcas L. \\ arbuscular mycorrhiza \\ hydrogel \\ macrophytes \\ Cerrado
}

\begin{abstract}
A B S T R A C T
The aim of this study was to evaluate, through mycorrhization (root colonization and number of spores of arbuscular mycorrhizal fungi - AMF), leaf acid phosphatase and soil chemical characteristics, the effects of the addition of residues (macrophytes and ash), hydrogel and the reintroduction of microorganisms in a degraded area cultivated with jatropha. Degradation occurred when the surface soil was removed during the construction of a hydroelectric power plant. The experiment was set in a randomized block design, using a $2 \times 2 \times 4$ factorial scheme, i.e., two inoculation treatments (with and without soil-inoculum), two hydrogel treatments (with and without) and four with the addition of residues (macrophytes - MAC, ash, MAC + ash and control, without residues) applied in the planting hole, with 4 replicates and 5 plants in each replicate. Soil from preserved Cerrado area was used as a source of microorganisms, including AMF. The conclusion is that, after 12 months of planting, the hydrogel increased root colonization, while the chemical characteristics of the degraded soil responded positively to the addition of MAC and MAC + ash, with increase in $\mathrm{pH}$ and $\mathrm{SB}$ and reduction of $\mathrm{Al}$ and $\mathrm{H}+\mathrm{Al}$. The addition of the soil-inoculum, along with MAC and MAC + ash, promoted higher mycorrhizal colonization and number of spores and reduced amounts of leaf acid phosphatase, indicating increased absorption of $\mathrm{P}$ by the host.
\end{abstract}

\author{
Palavras-chave: \\ Jatropha curcas L. \\ micorriza arbuscular \\ hidrogel \\ macrófitas \\ cerrado
}

\section{Adição dos resíduos e reintrodução de micro-organismos no cultivo do pinhão-manso em área degradada}

\section{R E S U M O}

O objetivo do trabalho foi avaliar, por meio da micorrização (colonização e número de esporos de fungos micorrízicos arbusculares - FMA), da fosfatase ácida foliar e das características químicas do solo, os efeitos da adição de resíduos (macrófitas e cinza), de hidrogel e da reintrodução de micro-organismos em área degradada, cultivada com pinhão-manso. A degradação ocorreu quando o solo de superfície foi removido durante a construção da usina hidroelétrica. O delineamento experimental foi blocos casualizados em esquema fatorial $2 \times 2 \times 4$, ou seja, 2 tratamentos de inoculação (com e sem solo-inóculo), 2 com hidrogel (com e sem) e 4 com adição de resíduos (macrófitas - MAC, cinza - CNZ, $\mathrm{MAC}+\mathrm{CNZ}$ e controle sem resíduos) colocados na cova de plantio, com 4 repetições e 5 plantas por repetição. Solo de cerrado preservado foi utilizado como fonte de microorganismos incluindo FMA. Conclui-se que, aos 12 meses do plantio, o hidrogel elevou a colonização radicular enquanto as características químicas do solo degradado responderam positivamente à adição de MAC e de MAC + CNZ, com aumento do pH e SB e redução de $\mathrm{Al}$ e $\mathrm{H}+\mathrm{Al}$. A adição de solo-inóculo proporcionou, juntamente com os MAC e MAC + $\mathrm{CNZ}$, maior colonização e número de esporos micorrízica e reduziu os valores da fosfatase ácida indicando maior absorção de $\mathrm{P}$ pelo hospedeiro. 


\section{INTRODUCTION}

Environments modified by engineering works, such as the construction of hydroelectric power plants, or subjected to intense erosive processes, which alter their original characteristics beyond the limit of natural recovery (Noffs et al., 2011), lead to the occurrence of degraded areas in which soil conditions are far from the natural ones (Rodrigues et al., 2007). This set of environmental problems requires alternatives that improve the occupation and allow the recovery of these areas, such as the selection of plant species to be cultivated. Described as a rustic species with low nutritional demand, jatropha (Jatropha curcas L.) has been considered as an agricultural option for arid and semiarid areas (Arruda et al., 2004).

Another important component in the soil-plant system is the microorganisms (Folli-Pereira et al., 2012), among which arbuscular mycorrhizal fungi are essential in the establishment and adaptation of plants in disturbed areas, since their hyphae colonize the soil, favor the formation and stability of its aggregates and promote improvements in the nutritional state of the host, facilitating the absorption of phosphorus $(\mathrm{P})$ and micronutrients (Zahawi, 2005) and improving the water-plant relationship. However, little is known about the response of jatropha to mycorrhization.

Used to evaluate the nutritional conditions of plant species, the determination of the activity of acid phosphatase enzyme is recommended when there are conditions of $\mathrm{P}$ deficiency (Kouas et al., 2009); thus, it is directly related to mycorrhizal efficiency.

In the process of recovery of a degraded soil, it is also important to improve the nutritional conditions through the supply of organic material, which may occur by the addition of organic and agro-industrial residues. As an organic residue, macrophytes collected in lakes and rivers have been recommended, for having biomass rich in macro and micronutrients, which positively influence soil physical, chemical and biological properties (Sampaio \& Oliveira, 2005). Another residue, the ash from the burning of sugarcane bagasse, is also a source of macro and micronutrients, retains humidity and can partially correct soil acidity (Ferreira et al., 2012).

Hydrogel, an absorbing polymer with capacity to store large amounts of water and release it gradually, is an alternative for situations of low water availability in the soil. It allows longer intervals between irrigations and improves plant development (Coelho et al., 2008), without reacting with soil constituents (Miranda et al., 2011).

In order to favor the recovery of degraded soils, this study aimed to evaluate the effects of the addition of residues (macrophytes and ash), hydrogel and the reintroduction of microorganisms in a degraded soil, cultivated with jatropha, during the construction of a hydroelectric power plant.

\section{Material ANd Methods}

The experiment was conducted during 12 months and started in October 2010, with the preparation of an area with degraded soil, which was originally covered with 'Cerrado' (bioma). In the 1960s, with the construction of the hydroelectric power plant of Ilha Solteira, the area was deforested and used as "soil borrow area", from which soil layers of up to $12 \mathrm{~m}$ deep were removed.

Located at the Farm of Teaching, Research and Extension of the São Paulo State University (UNESP), Campus of Ilha Solteira-SP, the area is found on the right side of the Paraná River, downstream of the Hydroelectric Power Plant, in the municipality of Selvíria-MS, Brazil ( $20^{\circ} 22^{\prime} \mathrm{S}$; $\left.51^{\circ} 22^{\prime} \mathrm{W}\right)$. The mean altitude is $335 \mathrm{~m}$ and the climate is $\mathrm{Aw}$, with mean annual temperature of $23.7^{\circ} \mathrm{C}$ and mean annual rainfall of $1,300 \mathrm{~mm}$. Temperature, rainfall and relative humidity in the region, along the 12 months of experiment, are shown in Figure 1. The soil in the area was originally classified as distrofic Red Latosol.

The experiment was set in randomized blocks, in a $2 \mathrm{x}$ $2 \times 4$ factorial scheme, with 2 inoculation treatments (with and without), 2 hydrogel treatments (with and without) and 4 treatments of residues applied in the planting hole (macrophytes, ash, macrophytes + ash and control, without the addition of residues), with four replicates (blocks) and 5 evaluated plants per treatment. Each block occupied an area of $960 \mathrm{~m}^{2}(30 \times 32 \mathrm{~m})$, which comprised 6 rows with 10 jatropha plants per row (160 plants).

For the initial characterization of the area, the $2 \mathrm{~mm}$, air-dry soil (ADS) of a composite soil sample, formed by four single samples collected in the layer of $0-0.10 \mathrm{~m}$, was analyzed for granulometry $\left(\right.$ Clay $=450$; Silt $=128$; Sand $\left.=422 \mathrm{~g} \mathrm{~kg}^{-1}\right)$, through the pipette method (EMBRAPA, 2011), and fertility, using the methodology proposed by Raij et al. (2001). The following results were obtained: $\mathrm{P}\left(\mathrm{mg} \mathrm{dm}^{-3}\right)=4.0$; organic matter - OM $\left(\mathrm{g} \mathrm{dm}^{-3}\right)=7.0 ; \mathrm{pH}\left(\mathrm{CaCl}_{2}\right)=4.2 ; \mathrm{K}=0.4 ; \mathrm{Ca}\left(\mathrm{mmol}_{\mathrm{c}} \mathrm{dm}^{-3}\right)=$ 1.0; $\mathrm{Mg}\left(\mathrm{mmol}_{\mathrm{c}} \mathrm{dm}^{-3}\right)=1.0 ; \mathrm{H}+\mathrm{Al}\left(\mathrm{mmol}_{\mathrm{c}} \mathrm{dm}^{-3}\right)=13.0 ; \mathrm{Al}$ $\left(\mathrm{mmol}_{c} \mathrm{dm}^{-3}\right)=2.0$; some of bases $-\mathrm{SB}\left(\mathrm{mmol} \mathrm{dm}^{-3}\right)=2.4$ and the number of arbuscular mycorrhizal fungi - AMF spores $=3$ spores per $100 \mathrm{~g}$ of dried soil.

The number of autochthonous AMF spores was determined using a sample of $100 \mathrm{~g}$, processed according to the association of the methods of decantation and wet sieving (Gerdemann \& Nicolson, 1963) and centrifugation and sucrose flotation (Jenkins, 1964). Counting was performed on acrylic plate with concentric rings, under a stereoscopic microscope (40x).

The soil-inoculum was prepared using the soil collected from four points in the layer of $0-0.10 \mathrm{~m}$, in an area of preserved

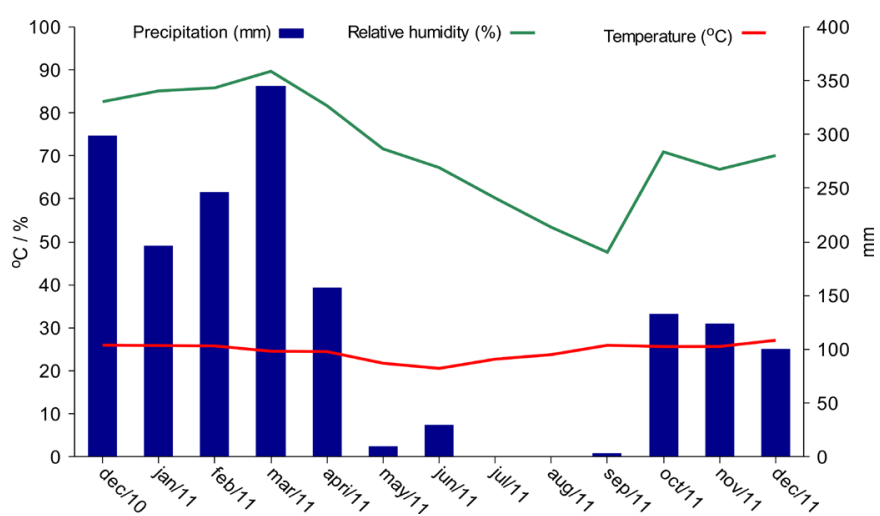

Figure 1. Means of temperature $\left({ }^{\circ} \mathrm{C}\right)$, precipitation $(\mathrm{mm})$ and relative air humidity (\%) for the experimental period of 12 months (UNESP - Farm of Teaching, Research and Extension) 
Cerrado. Before being used as an inoculum, the soil was cultivated with Urochloa decumbens Stapf in a greenhouse. The determination of the number of autochthonous AMF spores followed the previously described methodologies, which found 300 spores per $100 \mathrm{~g}$ of soil-inoculum.

Jatropha seedlings, in the stage of 2 pairs of leaves, growing in tubes with commercial substrate were transplanted to plastic bags containing $2 \mathrm{~kg}$ of soil collected from the layer of $0.0-0.1 \mathrm{~m}$ in the experimental area and maintained in a nursery for 4 months, where they were daily watered. Before being transplanted to the field, the seedlings were transferred to the outside of the nursery, where they remained for 15 days for the adaptation to field conditions.

The macrophytes were collected at the Hydroelectric Power Plant Engenheiro Souza Dias (Jupiá), located in Três Lagoas-MS, and, according to Marcondes et al. (2003), are mainly composed of Egeria densa Planch., Egeria najas Planch., Ceratophyllum demersum L., Eichhornia azurea Kunth, Eichhornia crassipes (Mart.) Solms., Pistia stratiotes L. and Typha latifolia L. This biomass was air-dried and ground, in order to reduce and standardize its size (approximately $1 \mathrm{~cm}$ long). The material was analyzed for the contents of nutrients, according to Malavolta et al. (1997), and showed the following results: $\mathrm{N}=26 ; \mathrm{P}=3 ; \mathrm{K}=9.5 ; \mathrm{Ca}=25 \mathrm{~g} \mathrm{~kg}^{-1}$ of dry matter and $\mathrm{S}=33 ; \mathrm{B}=52 ; \mathrm{Zn}=96 ; \mathrm{Cu}=51 ; \mathrm{Fe}=248$ and $\mathrm{Mn}=127$ $\mathrm{mg} \mathrm{kg}{ }^{-1}$ of dry matter.

The ash, from the burning of the sugarcane bagasse in boilers, was collected at the ALCOVALE Sugar Mill, in the municipality of Aparecida do Tabuado-MS, and subjected to chemical analysis of the available elements (Raij et al., 2001). The following results were obtained: $\mathrm{P}\left(\mathrm{mg} \mathrm{dm}^{-3}\right)=54 ; \mathrm{OM}$ $\left(\mathrm{g} \mathrm{dm}^{-3}\right)=15 ; \mathrm{pH}\left(\mathrm{CaCl}_{2}\right)=5.0 ; \mathrm{K}\left(\mathrm{mmol}_{\mathrm{c}} \mathrm{dm}^{-3}\right)=5.6 ; \mathrm{Ca}$ $\left(\mathrm{mmol}_{\mathrm{c}} \mathrm{dm}^{-3}\right)=8 ; \mathrm{Mg}\left(\mathrm{mmol}_{\mathrm{c}} \mathrm{dm}^{-3}\right)=6 ; \mathrm{H}+\mathrm{Al}\left(\mathrm{mmol}_{\mathrm{c}} \mathrm{dm}^{-3}\right)$ $=40 ; \mathrm{Al}\left(\mathrm{mmol} \mathrm{dm}_{\mathrm{c}}^{-3}\right)=2$ and SB $\left(\mathrm{mmol}_{\mathrm{c}} \mathrm{dm}^{-3}\right)=19.6$.

The experimental area was subsoiled and harrowed to the depth of $0.40 \mathrm{~m}$. The holes were opened with diameter of $0.30 \mathrm{~m}$ and depth of $0.90 \mathrm{~m}$, using a hydraulic drill, at the spacing of $3 \times 2 \mathrm{~m}$. The bottom half of the hole was filled with the removed soil and the top half with a mixture of soil and residues, according to the established treatments. After that, the seedlings were planted.

The treatments with macrophytes received the equivalent to $15,000 \mathrm{~kg} \mathrm{ha}^{-1}$ of dry matter per hole and, for the treatments with ash, the equivalent to $30,000 \mathrm{~kg} \mathrm{ha}^{-1}$. As a basic conditioning, all treatments received correction and chemical fertilization in minimum amounts, in order not to interfere with the inoculation treatments, using dolomitic limestone $\left(59.4 \mathrm{~kg} \mathrm{ha}^{-1}\right)$, ammonium sulfate $\left(39.6 \mathrm{~kg} \mathrm{ha}^{-1}\right)$, single superphosphate $\left(23.1 \mathrm{~kg} \mathrm{ha}^{-1}\right)$ and potassium chloride $\left(2.300 \mathrm{~kg} \mathrm{ha}^{-1}\right)$.

The inoculation treatments, at the planting of seedlings, received $200 \mathrm{~g}$ of soil-inoculum, which promoted 600 spores of AMF per hole.

The hydrogel (Stockosorb, manufactured by DegussaHüls Ltda., based on polymers formed by acrylamide, acrylic acid based on potassium salt) was prepared by diluting $3 \mathrm{~g}$ of the product in $700 \mathrm{~mL}$ of water and applied on the surface, immediately after planting the seedlings, and covered with a layer of a few centimeters of soil.
In order to facilitate water retention, from watering or rainfall, crowning was performed around the holes before planting the seedlings; hoeing was performed in the perimeter of the crown whenever necessary.

After 12 months of introduction of jatropha seedlings to the field, one soil sample, composed of 5 single samples, was collected in each replicate, in the holes and close to the plants, using a soil column cylinder auger at the depth of $0.10 \mathrm{~m}$. The $2 \mathrm{~mm}$ ADS samples were analyzed for fertility and number of AMF spores, according to the previously described methodologies.

The roots found during the sieving of soil samples were separated, washed in running water and preserved in alcohol (50\%). For the determination of the percentage of mycorrhizal colonization, the preserved roots were colored with $0.05 \%$ trypan blue in lactoglycerol (Phillips \& Hayman, 1970). The percentage of colonized segments was determined through the evaluation of 100 segments of thin roots, about $1 \mathrm{~cm}$ long, per sample, under optical microscope.

The acid phosphatase activity for leaves was evaluated according to the procedure described by Besford (1980), using $10 \mathrm{~g}$ of recently collected leaf blade, which were incubated in $8 \mathrm{~mL}$ of p-nitrophenylphosphate (p-NPP) in sodium acetate buffer ( $\mathrm{pH} 4.0)$. After incubation for $20 \mathrm{~min}$, at $30^{\circ} \mathrm{C}$, protected from the light, $5 \mathrm{~mL}$ of the mixture were alkalinized with $2 \mathrm{~mL}$ of $\mathrm{NaOH}\left(2 \mathrm{~mol} \mathrm{~L}^{-1}\right)$, for the colorimetric $(420 \mathrm{~nm})$ estimation of the paranitrophenyl formed, in mg p-NPP g-1 $\mathrm{h}^{-1}$.

The obtained results were subjected to analysis of variance and, when F-test significance was observed, means were compared by the Scott-Knott test at 0.05 probability level.

\section{Results AND Discussion}

After 12 months of experiment installation, the addition of soil-inoculum to the degraded soil resulted in the reduction of $\mathrm{P}$ contents and sum of bases (SB) (Table 1). The treatments with residues of macrophytes and macrophytes + ash promoted increments in $\mathrm{pH}$ and $\mathrm{SB}$ and reductions in $\mathrm{H}+\mathrm{Al}$ and $\mathrm{Al}$.

The addition of residues caused slight increment in soil organic matter $(\mathrm{OM})$, while $\mathrm{H}+\mathrm{Al}$ and $\mathrm{Al}$ showed the highest means, both in the control treatment and in the ash treatment. The addition of sources of organic material has been indicated with the objective of improving soil properties (Kitamura et al., 2008).

The amount of OM reported by Araújo et al. (2007) in soil under different uses and native Cerrado was 3 times higher than those in the present study, which suggests that, despite the addition of residues, the current conditions of the degraded soil remain far from the natural one.

In the interaction of hydrogel and residues, soil $\mathrm{P}$ showed the highest means in the treatments with macrophytes, in the presence of hydrogel, and macrophytes + ash, in its absence (Tables 1 and 2). There was a slight increase in $\mathrm{P}$ contents with the addition of macrophytes, combined with hydrogel, followed by the treatment with addition of macrophytes + ash, in the absence of hydrogel (Table 2).

The association of macrophytes and hydrogel or macrophytes + ash may have favored the activity of the microbiota, for promoting a more humid environment, interfering with the 
Table 1. Means, F values and coefficients of variation $(\mathrm{CV} \%)$ for chemical characteristics of a degraded soil under the treatments of reintroduction of microorganisms, hydrogel and residues (macrophytes, ash, macrophytes + ash and control, without residues) applied to the planting hole

\begin{tabular}{|c|c|c|c|c|c|c|c|}
\hline \multirow{2}{*}{\multicolumn{2}{|c|}{ Treatments }} & \multirow{3}{*}{$\begin{array}{c}P \\
\left(\mathrm{mg} \mathrm{dm}^{-3}\right) \\
5.75 \mathrm{~b}\end{array}$} & \multirow{2}{*}{$\begin{array}{c}O M \\
\left(g d^{-3}\right)\end{array}$} & \multirow{3}{*}{$\begin{array}{c}\mathrm{pH} \\
\mathrm{CaCl}_{2} \\
4.52\end{array}$} & \multirow{2}{*}{\multicolumn{3}{|c|}{$\frac{\mathrm{Al}}{\left(\mathrm{mmol}_{\mathrm{G}} \mathrm{dm}^{3}\right)}$}} \\
\hline & & & & & & & \\
\hline \multirow{2}{*}{ Inoculum (I) } & With I & & 9.21 & & 24.25 & 5.71 & $8.15 b$ \\
\hline & Without I & $6.43 \mathrm{a}$ & 9.46 & 4.57 & 23.40 & 5.18 & $10.20 \mathrm{a}$ \\
\hline \multirow[b]{2}{*}{ Hydrogel $(H)$} & With $\mathrm{H}$ & 6.09 & 9.21 & 4.52 & 24.03 & 5.34 & 9.25 \\
\hline & Without H & 6.09 & 9.46 & 4.57 & 23.62 & 5.56 & 9.09 \\
\hline \multirow{4}{*}{ Residues (R) } & Macrophytes (M) & 6.43 & $9.37 \mathrm{a}$ & $4.64 \mathrm{a}$ & $21.62 b$ & $3.56 \mathrm{~b}$ & $11.40 \mathrm{a}$ \\
\hline & Ash (A) & 5.75 & $9.31 \mathrm{a}$ & $4.43 \mathrm{~b}$ & $25.93 \mathrm{a}$ & $7.18 \mathrm{a}$ & $7.49 \mathrm{~b}$ \\
\hline & $M+A$ & 6.50 & $9.81 \mathrm{a}$ & $4.71 \mathrm{a}$ & $21.81 b$ & $3.56 \mathrm{~b}$ & $11.19 \mathrm{a}$ \\
\hline & Control & 5.68 & $8.87 \mathrm{~b}$ & $4.30 \mathrm{~b}$ & $25.93 \mathrm{a}$ & $7.50 \mathrm{a}$ & $6.20 \mathrm{~b}$ \\
\hline \multirow{6}{*}{$F$ values } & 1 & $5.441^{*}$ & $1.233^{\mathrm{ns}}$ & $2.473^{\text {ns }}$ & $2.293^{\text {ns }}$ & $2.614^{\mathrm{ns}}$ & $6.221^{*}$ \\
\hline & $\mathrm{H}$ & $0.003^{\mathrm{ns}}$ & $0.299^{\text {ns }}$ & $2.472^{\text {ns }}$ & $0.613^{\text {ns }}$ & $0.443^{\text {ns }}$ & $0.007^{\text {ns }}$ \\
\hline & $\mathrm{R}$ & $2.136^{\mathrm{ns}}$ & $3.112^{\star}$ & $18.741^{\star \star}$ & $18.354^{\star \star}$ & $44.381^{\star \star}$ & $9.808^{\star \star}$ \\
\hline & $\mathrm{I} \times \mathrm{H}$ & $0.736^{\mathrm{ns}}$ & $0.100^{\mathrm{ns}}$ & $5.971^{\star \star}$ & $0.123^{\text {ns }}$ & $3.274^{\text {ns }}$ & $0.732^{\text {ns }}$ \\
\hline & $I \times R$ & $1.869^{\text {ns }}$ & $0.592^{\mathrm{ns}}$ & $1.165^{\text {ns }}$ & $1.466^{\mathrm{ns}}$ & $1.532^{\mathrm{ns}}$ & $1.314^{\mathrm{ns}}$ \\
\hline & $\mathrm{H} \times \mathrm{R}$ & $4.524^{* *}$ & $0.715^{\mathrm{ns}}$ & $1.490^{\text {ns }}$ & $0.396^{\text {ns }}$ & $0.755^{\mathrm{ns}}$ & $0.933^{\text {ns }}$ \\
\hline CV (\%) & & 8 & 4 & 3 & 5 & 12 & 16 \\
\hline
\end{tabular}

Table 2. Follow-up analysis of significant interactions for phosphorus, and $\mathrm{pH}$ of a degraded soil under treatments of reintroduction of microorganisms $(\mathrm{I})$, hydrogel $(\mathrm{H})$ and residues (macrophytes, ash, macrophytes + ash and control, without residues) applied to the planting hole

\begin{tabular}{|c|c|c|c|c|}
\hline \multirow{2}{*}{ Treatment } & Macrophytes (M) & Ash (A) & $M+A$ & Control \\
\hline & \multicolumn{4}{|c|}{ Phosphorus $\left(\mathrm{mg} \mathrm{dm}^{-3}\right)$} \\
\hline With $\mathrm{H}$ & $7.25 \mathrm{aA}$ & $5.50 \mathrm{aB}$ & $5.87 \mathrm{bB}$ & $5.50 \mathrm{aB}$ \\
\hline \multirow{3}{*}{ Without $\mathrm{H}$} & $5.62 \mathrm{bB}$ & $6.00 \mathrm{aB}$ & $7.12 \mathrm{aA}$ & $5.62 \mathrm{aB}$ \\
\hline & With H & Without H & & \\
\hline & \multicolumn{2}{|c|}{$\mathrm{pH}\left(\mathrm{CaCl}_{2}\right)$} & & \\
\hline With I & $4.53 \mathrm{aA}$ & $4.50 \mathrm{bA}$ & & \\
\hline Without I & $4.50 \mathrm{aB}$ & $4.65 \mathrm{aA}$ & & \\
\hline
\end{tabular}

Means followed by the same letter, lowercase in the column and uppercase in the row, for each variable, do not differ by Scott-Knott test at 0.05 probability level

dynamics of $\mathrm{P}$ in the soil, which, according to Santos et al. (2008), is associated with environmental factors such as $\mathrm{pH}$, humidity, temperature and aeration, among others, which control the activity of microorganisms, immobilizing or releasing, in this case, orthophosphate ions.

The interaction of inoculation $\mathrm{x}$ hydrogel caused significant effects only on soil $\mathrm{pH}$ and the highest value was observed in the treatment with absence of inoculation and hydrogel (Table 2). The residues incorporated into the soil allowed the increase of $\mathrm{pH}$ from 4.2, in the initial characterization of the soil, to 4.64 , with the addition of macrophytes, and to 4.7 , when they were associated with ash (Tables 1 and 2). As previously mentioned, the highest $P$ values were observed in the same treatments, possibly due to the alterations in $\mathrm{pH}$, which were sufficient to influence the chemical characteristic of the soil.

Although $\mathrm{pH}$ may interfere with soil chemical properties, these modifications are dependent on a large number of factors and processes, including the microbial activity on OM decomposition. Thus, the data suggest that there was immobilization of $\mathrm{P}$ and of bases by the microorganisms during the process of transformation of OM. The greater immobilization is directly related to the lower availability of the nutrient in the soil.
Considering the $\mathrm{P}$ content in the ash $\left(53 \mathrm{mg} \mathrm{dm}^{-3}\right)$, detected in the initial characterization of the residue, its addition resulted in an effect smaller than expected, in relation to the concentration of available $\mathrm{P}$ in the soil, certainly due to the slow release of the nutrient resulting from the condition of degradation of the soil. Therefore, the period from experiment installation until the evaluations (12 months) must have been insufficient for an effective release of the nutrient (Table 2). Corrêa et al. (2005) also observed that a short period (3 months) of guava residue incubation was not sufficient for an effective OM mineralization, with release of $P$.

However, no reports were found in the literature on the decomposition rate of residues such as sugarcane bagasse ash. In spite of that, Silveira (2010), working with residue, observed that soil P contents suffered an expressive increase, which was proportional to the applied doses $\left(20\right.$ to $\left.100 \mathrm{tha}^{-1}\right)$. These increases ranged from 50 to $425 \%$ and were expected, due to the presence of $\mathrm{P}$ in the ash.

Considered as an indicator of the necessity of $\mathrm{P}$ by plants and classified based on the $\mathrm{pH}$ of action, the activity of leaf acid phosphatase will be higher, the lower is the amount of available P (Gatiboni et al., 2008). In the present study, there was lower acid phosphatase activity in the treatments with inoculation and with addition of macrophytes and macrophytes + ash, confirming the beneficial effects of macrophytes (Table 3 ).

Scabora et al. (2010) reported that leaf acid phosphatase of Croton floribundus Spreng, grown in a soil from the same degraded area of the present study, showed the lowest values in the treatment that received soil-inoculum, which evidences the importance of microbial activity, such as AMF, for the absorption of nutrients by plants. Tristão et al. (2006), studying coffee plants under the influence of AMF in different substrates, observed that plants inoculated and cultivated in different organic substrates showed reduction of about $40 \%$ in acid phosphatase activity, compared with non-mycorrhized.

Although jatropha is considered as a rustic plant, with high adaptability to low fertility soils, little is known about its behavior in response to AMF inoculation. Inoculation 
Table 3. Means, $\mathrm{F}$ values and coefficients of variation $(\mathrm{CV} \%)$ of leaf acid phosphatase, number of spores and percent colonization by arbuscular mycorrhizal fungi, in a degraded soil under the treatments of reintroduction of microorganisms, hydrogel and residues (macrophytes, ash, macrophytes + ash and control, without residues) applied to the planting hole

\begin{tabular}{|c|c|c|c|c|}
\hline \multicolumn{2}{|c|}{ Treatments } & $\begin{array}{l}\text { Acid Phosphatase } \\
m g \text { p-NPP g-1 } h^{-1}\end{array}$ & $\begin{array}{c}\text { AMF spores } \\
\text { n. } x 100 \mathrm{~g} \text { dry soil }\end{array}$ & $\begin{array}{c}\text { Colonization } \\
\%\end{array}$ \\
\hline \multirow{2}{*}{ Inoculum (I) } & With I & $5.52 \mathrm{~b}$ & $37.81 \mathrm{a}$ & $47.87 \mathrm{a}$ \\
\hline & Without I & $8.20 \mathrm{a}$ & $12.17 \mathrm{~b}$ & $8.65 b$ \\
\hline \multirow{2}{*}{ Hydrogel (H) } & With $\mathrm{H}$ & 6.96 & $23.67 b$ & $29.42 \mathrm{a}$ \\
\hline & Without $\mathrm{H}$ & 7.00 & $26.30 \mathrm{a}$ & $27.10 \mathrm{~b}$ \\
\hline \multirow{4}{*}{ Residues (R) } & Macrophytes (M) & $6.02 \mathrm{~b}$ & $28.87 \mathrm{a}$ & $31.50 \mathrm{~b}$ \\
\hline & Ash $(A)$ & $7.98 \mathrm{a}$ & $19.64 \mathrm{C}$ & $24.30 \mathrm{C}$ \\
\hline & $M+A$ & $5.70 \mathrm{~b}$ & $28.63 \mathrm{a}$ & $33.19 \mathrm{a}$ \\
\hline & Control (T) & $8.00 \mathrm{a}$ & $22.81 \mathrm{~b}$ & $24.05 \mathrm{C}$ \\
\hline \multirow{6}{*}{ F values } & I & $477.482^{* *}$ & $1310.871^{* *}$ & $8276.773^{* *}$ \\
\hline & $\mathrm{H}$ & $0.434^{\mathrm{ns}}$ & $22.216^{\star \star}$ & $14.427^{\star *}$ \\
\hline & $\mathrm{R}$ & $107.252^{* *}$ & $35.568^{* *}$ & $76.275^{* *}$ \\
\hline & $\mathrm{IxH}$ & $0.097^{\mathrm{ns}}$ & $21.080^{* *}$ & $11.072^{* *}$ \\
\hline & $\mathrm{I} \times \mathrm{R}$ & $1.052^{\text {ns }}$ & $20.924^{* *}$ & $36.213^{\star *}$ \\
\hline & $\mathrm{H} \times \mathrm{R}$ & $1.768^{\text {ns }}$ & $11.465^{* \star}$ & $1.875^{\text {ns }}$ \\
\hline CV (\%) & & 3 & 6 & 3 \\
\hline
\end{tabular}

Means followed by the same letter in the column, per treatment, do not differ by Scott-Knott test at 0.05 probability level; ${ }^{* \star}$ and ${ }^{*}$ Significant at 0.01 and 0.05 , respectively; ${ }^{\text {ns Not significant }}$

with soil-inoculum proved to be efficient for mycorrhization, increasing the number of spores by 3 times and percent colonization by 5 times (Table 3 ).

Root colonization showed the highest means in the treatments with inoculation and residues, and the interaction between these treatments also influenced root sporulation and colonization positively, especially the treatment with macrophytes + ash with inoculation (Table 4). These results can be justified by the benefits of the addition of residues in the improvement of soil and moisture conditions. Caravaca et al. (2004) reported that the joint application of organic substrates resulted in positive synergetic effect on mycorrhization, evidencing the importance of moisture for the AMF species.

The effects of hydrogel on root colonization were small, but contributed to increasing mycorrhizal colonization from $8.65 \%$ (without inoculation) to $47.85 \%$ (with inoculation), regardless of the hydrogel (Table 4). It was expected an

Table 4. Follow-up analysis of significant interactions for the number of spores and colonization by arbuscular mycorrhizal fungi in jatropha cultivated in a degraded soil under the treatments of reintroduction of microorganisms (I), hydrogel $(\mathrm{H})$ and residues (macrophytes, ash, macrophytes + ash and control, without residues) applied to the planting hole

\begin{tabular}{|c|c|c|c|c|}
\hline Treatment & $\begin{array}{l}\text { Macrophytes } \\
\text { (M) }\end{array}$ & $\begin{array}{l}\text { Ash } \\
\text { (A) }\end{array}$ & $M+A$ & Control \\
\hline & \multicolumn{4}{|c|}{ Spores (n x $100 \mathrm{~g}$ dry soil) } \\
\hline With I & $38.77 \mathrm{aB}$ & $29.49 \mathrm{aC}$ & $46.25 \mathrm{aA}$ & $36.72 \mathrm{aB}$ \\
\hline Without I & $18.97 \mathrm{bA}$ & $9.79 \mathrm{bB}$ & $11.02 \mathrm{bB}$ & $8.90 \mathrm{bB}$ \\
\hline With $\mathrm{H}$ & $24.25 \mathrm{bB}$ & $18.12 \mathrm{aC}$ & $30.00 \mathrm{aA}$ & $22.32 \mathrm{aB}$ \\
\hline \multirow[t]{2}{*}{ Without $\mathrm{H}$} & $33.50 \mathrm{aA}$ & $21.15 \mathrm{aC}$ & $27.27 \mathrm{aB}$ & $23.30 \mathrm{aC}$ \\
\hline & \multicolumn{4}{|c|}{ Colonization (\%) } \\
\hline With I & $53.32 \mathrm{aB}$ & $40.65 \mathrm{aC}$ & $57.41 \mathrm{aA}$ & $40.08 \mathrm{aC}$ \\
\hline \multirow[t]{3}{*}{ Without I } & $9.67 \mathrm{bA}$ & $7.95 \mathrm{bA}$ & $8.97 \mathrm{bA}$ & $8.20 \mathrm{bA}$ \\
\hline & With H & Without H & With H & Without H \\
\hline & \multicolumn{2}{|c|}{ Spores (n.x100 g dry soil) } & \multicolumn{2}{|c|}{ Colonization (\%) } \\
\hline With $\mathrm{H}$ & $37.93 \mathrm{aA}$ & $37.68 \mathrm{aA}$ & $50.14 \mathrm{aA}$ & $45.59 \mathrm{aB}$ \\
\hline Without H & $9.41 \mathrm{bB}$ & $14.93 \mathrm{bA}$ & $8.70 \mathrm{bA}$ & $8.61 \mathrm{bA}$ \\
\hline
\end{tabular}

Means followed by the same letter, lowercase in the column and uppercase in the row, for each variable, do not differ by Scott-Knott test at 0.05 probability level increase of sporulation in the presence of hydrogel, since it promotes greater water retention and soil moisture directly influences sporulation, spore germination and mycelial growth (Cavalcante et al., 2009), suggesting that the amount of hydrogel may have been insufficient for the degraded soil.

The use of residues can contribute to symbiosis, indicating the treatments of macrophytes + ash and macrophytes as promising, because AMF colonization involves a series of morpho-physiological and biochemical events that are regulated by the interaction between plants and fungi, as well as environmental factors (Costa \& Lovato, 2011).

\section{Conclusions}

1. The chemical characteristics of the degraded soil responded positively to the addition of macrophytes and macrophytes + ash, with increase in $\mathrm{pH}$ and $\mathrm{SB}$ and reduction in $\mathrm{Al}$ and $\mathrm{H}+\mathrm{Al}$.

2. The inoculation of microorganisms and the treatments with macrophytes and macrophytes + ash increased the number of spores and the percentage of mycorrhizal colonization and reduced leaf acid phosphatase, indicating greater $\mathrm{P}$ absorption by the host.

3. The application of hydrogel favored $\mathrm{P}$ when associated with the addition of macrophytes.

\section{ACKnowledgments}

To the Coordination for the Improvement of Higher Education Personnel - CAPES, for the scholarship to the first author, and to the National Council for Scientific and Technological Development - CNPq, for the research productivity grant to the last author.

\section{Literature Cited}

Araújo, R.; Goedert, W. J.; Lacerda, M. P. C. Qualidade de um solo sob diferentes usos e sob cerrado nativo. Revista Brasileira de Ciência do Solo, v.31, p.1099-1108, 2007. http://dx.doi.org/10.1590/S010006832007000500025 
Arruda, F. P.; Beltrão, N. E. de M.; Andrade, A. P.; Pereira, W. E.; Severino, L. S. Cultivo de pinhão manso (Jatropha curca L.) como alternativa para o semi-árido nordestino. Revista Brasileira de Oleaginosas e Fibrosas, v.8, p.789-799, 2004.

Besford, R. T. A rapid tissue test for diagnosing phosphorus deficiency in the tomato plant. Annals of Botany, v.45, p.225-227, 1980.

Caravaca, F.; Alguacil, M. M.; Azcón, R.; Díaz, G.; Roldán, A. Com-paring the effectiveness of mycorrhizal inoculation and amendment with sugar beet, rock phosphate and Aspergillus niger to enhance field performance of the leguminous shrub Dorycnium pentaphyllum L. Applied Soil Ecology, v.25, p.169-180, 2004. http://dx.doi.org/10.1016/j.apsoil.2003.08.002

Cavalcante, U. M. T.; Goto, B. T.; Maia, L. C. Aspectos da simbiose micorrízica arbuscular. Anais da Academia Pernambucana de Ciência Agronômica, v.5/6, p.180-208, 2008-2009.

Coelho, J. B. M.; Barros, M. F. C.; Correa, M. M.; Wanderley, R. A.; Coelho Júnior, J. M.; Figueiredo, J. L. C. Efeito do polímero hidratassolo sobre propriedades físico-hídricas de três solos. Revista Brasileira de Ciências Agrárias, v.3, p.253-259, 2008. http://dx.doi.org/10.5039/agraria.v3i3a238

Corrêa, M. C. M.; Fernandes, G. C.; Prado, R. M.; Natale, W. Propriedades químicas do solo tratado com resíduo orgânico da indústria processadora de goiabas. Revista Brasileira de Agrociência, v.11, p.241-243, 2005.

Costa, M. D.; Lovato, P. E. Micorrizas arbusculares e a supressão de patógenos. In: Klauberg Filho, O.; Mafra, A. L.; Gatiboni, L. C. Tópicos em ciência do solo. Viçosa, MG, Sociedade Brasileira de Ciência do Solo, v.6, p.119-139, 2011.

EMBRAPA - Empresa Brasileira de Pesquisa Agropecuária. Manual de métodos de análises de solo. 2.ed. Rio de Janeiro: Ministério da Agricultura e do Abastecimento, 2011. 225p.

Ferreira, E. B.; Fageria, N. K.; Didonet, A. D. Chemical properties of an Oxisol under organic management as influenced by application of sugarcane bagasse ash. Revista Ciência Agronômica, v.43, p.28-236, 2012. http://dx.doi.org/10.1590/ S1806-66902012000200004

Folli-Pereira, M. S.; Meira-Haddad, L. S. A.; Bazzolli, D. M. S; Kasuya, M. C. M. Micorriza arbuscular e a tolerância das plantas ao estresse. Revista Brasileira de Ciência do Solo, v.36, p.1663-1679, 2012. http://dx.doi.org/10.1590/S0100-06832012000600001

Gatiboni, L. C.; Kaminski, J.; Rheinheimer, D. S.; Brunetto, G. Fósforo da biomassa microbiana e atividade de fosfatases ácidas durante a diminuição do fósforo disponível no solo. Pesquisa Agropecuária Brasileira, v.43, p.1085-1091, 2008. http://dx.doi.org/10.1590/ S0100-204X2008000800019

Gerdemann, J. W.; Nilcolson, T. H. Spores of mycorrhizal endogone species extracted from soil by wet sieving and decanting. Transaction of British Mycological Society, v.46, p.234-244, 1963. http://dx.doi.org/10.1016/S0007-1536(63)80079-0

Jenkins, W. R. A rapid centrifugal-flotation technique for separating nematodes from soil. Plant and Soil, v.73, p.288-300, 1964.

Kitamura, A. E.; Alves, M. C.; Suzuki, L. G. A. S.; Gonzalez, A. P. Recuperação de um solo degradado com a aplicação de adubos verdes e lodo de esgoto. Revista Brasileira de Ciência do Solo, v.32, p.405-416, 2008. http://dx.doi.org/10.1590/S010006832008000100038
Kouas, S.; Louche, J.; Debez, A.; Plassard, C.; Drevon, J. J.; Abdelly, C. Effect of phosphorus deficiency on acid phosphate and phytase activities in common bean (Phaseolus vulgaris L.) under symbiotic nitrogen fixation. Symbiosis, v.47, p.141-149, 2009. http://dx.doi. org/10.1007/BF03179974

Malavolta, E.; Vitti, G. C.; Oliveira, S. A. Princípios, métodos e técnicas de avaliação. In: Malavolta, E.; Vitti, G. C.; Oliveira, S. A. ed. Avaliação do estado nutricional das plantas. Piracicaba: Associação Brasileira para Pesquisa da Potassa e do Fosfato, 1997. p.115-230.

Marcondes, D. A. S.; Mustafá, A. L.; Tanaka, R. H. Estudos para manejo integrado de plantas aquáticas no reservatório de Jupiá. In: Thomaz, S. M.; Bini, L. M. (ed.). Ecologia e manejo de macrófitas aquáticas. Maringá: Eduem, 2003. p.299-317

Miranda, M.; Oliveira, E. M.; Santos, K. C. F.; Freire, M. B. G. S.; Almeida, B. G. Condicionadores químicos e orgânicos na recuperação de solo salino-sódico em casa de vegetação. Revista Brasileira de Engenharia Agrícola e Ambiental, v.15, p.484-490, 2011. http://dx.doi.org/10.1590/S1415-43662011000500008

Noffs, P. S.; Galii, L. F.; Gonçalves, J. C. Recuperação de áreas degradadas da mata atlântica: Uma experiência da CESP Companhia Energética de São Paulo. São Paulo: CESP, 2011.p.148. Série Cadernos da Biosfera 3.

Phillips, J. M.; Hayman, D. S. Improved procedures for clearing roots for rapid assessment of infection. Transaction of British Mycology Society, v.55, p.158-161, 1970. http://dx.doi.org/10.1016/S00071536(70)80110-3

Raij, B. van; Andrade, J. C.; Cantarella, H.; Quaggio, J. A. Análise química para avaliação da fertilidade de solos tropicais. Campinas: Instituto Agronômico, 2001. 285p.

Rodrigues, G. B.; Maltoni, K. L.; Cassiolato, A. M. R. Dinâmica da regeneração do subsolo de áreas degradadas dentro do bioma Cerrado. Revista Brasileira de Engenharia Agrícola e Ambiental, v.11, p.73-80, 2007. http://dx.doi.org/10.1590/S1415-43662007000100010 Sampaio, E. V.S. B.; Oliveira, N.M. B. Aproveitamento da macrófita aquática Egeria densa como adubo orgânico. Planta Daninha, v.23, p.169-174, 2005. http://dx.doi.org/10.1590/S0100-83582005000200001

Santos, D. R. dos; Gatiboni , L. C.; Kaminski, J. Fatores que afetam a disponibilidade do fósforo e o manejo da adubação fosfatada em solos sob sistema plantio direto. Ciência Rural, v.38, p.576-586, 2008. http://dx.doi.org/10.1590/S0103-84782008000200049

Scabora, M. H.; Maltoni, K. L.; Cassiolato, A. M. R. Crescimento, fosfatase ácida e micorrização de espécies arbóreas, em solo de cerrado degradado. Bragantia, v.69, p.445-451, 2010. http://dx.doi. org/10.1590/S0006-87052010000200024

Silveira, T. Avaliação de cinza de caldeira de indústria de concentrados de frutas cítrica sobre as propriedades de solo degradado e solo cultivado com cana-de-açúcar. Jaboticabal: FCAV/UNESP, 2010. 45p. Dissertação Mestrado

Tristão, F. S. M.; Andrade, S. A. L.; Silveira, A. P. D. F. Fungos micorrízicos arbusculares na formação de mudas de cafeeiro, em substratos orgânicos comerciais. Bragantia, v.65, p.649-658, 2006. http://dx.doi.org/10.1590/S0006-87052006000400016

Zahawi, R. A. Establishment and growth of living fence species: An overlooked tool for the restoration of degraded areas in the tropics. Restoration Ecology, v.102, p.13-92, 2005. http://dx.doi. $\operatorname{org} / 10.1111 /$ j.1526-100x.2005.00011.x 